\title{
Pengaruh Takaran dan Frekuensi Aplikasi PGPR terhadap Pertumbuhan dan Hasil Tanaman Selada (Lactuca sativa $\mathbf{L}$.)
}

\author{
Yohanes F. Naihatia , Roberto I. C. O. Taolin ${ }^{\mathrm{b}}$, dan Aloysius Rusae \\ ${ }^{a}$ Fakultas Pertanian, Universitas Timor, Kefamenanu, TTU - NTT, Indonesia. \\ ${ }^{b}$ Fakultas Pertanian, Universitas Timor, Kefamenanu, TTU - NTT, Indonesia.
}

${ }^{c}$ Fakultas Pertanian, Universitas Timor, Kefamenanu, TTU - NTT, Indonesia.

\section{Article Info}

\section{Article history:}

Received 20 November 2017

Received in revised form 10 Desember 2017 Accepted 3 Januari 2018

\section{Keywords:}

Plant Growth Promoting Rhizobacteria

PGPR

Lactuca sativa $\mathrm{L}$.

\begin{abstract}
Abstrak
Penelitian ini bertujuan untuk mengetahui dan membuktikan pengaruh takaran dan frekuensi aplikasi PGPR terhadap pertumbuhan dan hasil tanaman selada dan juga mengetahui takaran dan frekuensi aplikasi PGPR yang tepat untuk mendapatkan pertumbuhan dan hasil tanaman selada yang terbaik. Rancangan yang digunakan adalah rancangan acak kelompok (RAK) faktorial dengan tiga kali ulangan. Faktor pertama adalah takaran PGPR yang terdiri dari tiga aras yakni $25 \mathrm{~g}, 50 \mathrm{~g}$ dan, $75 \mathrm{~g}$. Faktor yang kedua adalah frekuensi aplikasi yang terdiri dari tiga aras yakni tanpa penyiraman (kontrol), satu kali penyiraman dan, dua kali penyiraman. Hasil penelitian menunjukkan interaksi antara takaran dan frekuensi aplikasi PGPR terjadi pada semua parameter pertumbuhan dan hasil selada yakni tinggi tanaman, jumlah daun, luas daun, berat trubus baik segar maupun kering, berat akar baik segar maupun kering, berat tanaman baik segar maupun kering, berat tanaman per petak baik segar maupun kering dan indeks panen. Aplikasi PGPR sebanyak dua kali dengan takaran $25 \mathrm{~g}$ memberikan pertumbuhan dan hasil tanaman selada yang terbaik. @2018 dipublikasikan oleh Savana Cendana.
\end{abstract}

\section{Pendahuluan}

Selada (Lactuca sativa $\mathrm{L}$.) merupakan sayuran daun yang berasal dari daerah (negara) beriklim sedang. Menurut sejarahnya, tanaman selada telah dibudidayakan sejak 2500 tahun yang lalu. Tanaman selada berasal dari kawasan Amerika. Hal ini dibuktikan oleh Christoper Columbus pada tahun 1493 yang menemukan tanaman selada di daerah Hemisphere bagian barat dan Bahamas (AAK, 1994). Selanjutnya Wicaksono, (2008) menyatakan selada disukai oleh masyarakat, karena jenis sayur ini mengandung zat-zat gizi seperti protein vitamin B, vitamin C untuk memenuhi kebutuhan gizi masyarakat. Selada sebagai bahan makanan dapat dikomsumsi dalam bentuk segar sebagai lalapan yang dimakan bersama dengan bahan makanan lain.

Tanaman selada cepat menghasilkan akar tunggang yang dalam disertai dengan penebalan dan perkembangan ekstensif akar lateral. Pembuahan pada tanaman selada terjadi akibat penyerbukan sendiri ataupun dengan penyerbukan dengan bantuan serangga. Waktu panen selada berbeda-beda tergantung kultivar dan musim, umumnya berkisar dari 30-85 hari setelah pindah tanaman (Rubatzky \& Yamaguchi, 2012), hal ini sangat bermanfaat bagi petani untuk mendapatkan hasil tanaman dalam waktu yang relatif singkat.

Sesuai data Badan Pusat Statistik (BPS) Kabupaten Timor Tengah Utara (TTU), produktivitas selada mengalami penurunan pada tahun 2001-2003 yaitu pada tahun 2001 sebesar 4,252 t/ha sedangkan pada tahun 2003 menurun menjad 1,494 t/ha (BPS Kab. TTU, 2004), dari data yang ada menunjukkan perlunya suatu upaya untuk dapat meningkatkan produktivitas selada. Menurut Samadi (2014), prospek serapan pasar terhadap komoditas selada akan terus meningkat sejalan dengan peningkatan jumlah penduduk, peningkatan pendidikan masyarakat, peningkatan pendapatan dan kesejahteraan masyarakat, serta peningkatan kesukaan masyarakat terhadap selada.

Cara budidaya tanaman selada di Kabupaten TTU masih bersifat tradisional. Selada yang dibudidayakan dalam skala yang kecil dengan menggunakan pupuk dan pestisida kimia terus menerus tanpa memperhatikan kondisi tanah menyebabkan produktivitas menurun dan pada musim hujan tidak dibudidayakan karena tanaman ini rentan dengan hama dan penyakit.

Petani saat ini sudah semakin menyadari dampak negatif dari penggunaan pupuk kimia terhadap lingkungan, dari kesadaran ini muncul inisiatif untuk menggunakan pupuk yang ramah lingkungan. Pupuk hayati memiliki kelebihan dalam meningkatkan pertumbuhan tanaman sehingga hasil yang didapatkan lebih berlimpah. Figuiredo et al., (2010) menyatakan salah satu pupuk hayati yang dapat digunakan yakni Plant Growth Promoting Rhizobacteria (PGPR), yang biasa ditumbuhkan pada substrat cair, penggunaan PGPR sebagai pupuk cair in agar mudah diserap oleh akar tanaman dibandingkan pupuk padat.

PGPR merupakan konsorsium bakteri yang aktif mengkolonisasi akar tanaman yang berperan penting dalam meningkatkan pertumbuhan tanaman, hasil panen dan kesuburan lahan (Raka et al., 2012). Pemanfaatan PGPR dapat menjadi salah satu teknik unruk meningkatkan produktivitas selada di Kabupaten TTU. Beberapa penelitian telah membuktikan bahwa PGPR berpengaruh terhadap pertumbuhan dan hasil berbagai tanaman sayuran termasuk selada. Penelitian Onikawijaya (2015) melaporkan bahwa variasi konsentrasi PGPR umumnya memberikan hasil pertumbuhan selada yang lebih baik dibandingkan dengan kontrol. Sebelumnya, penelitian Syamsiah \& Rayani (2014) pada tanaman cabai juga melaporkan bahwa konsentrasi PGPR 1,25\% meningkatkan tinggi tanaman dan konsentrasi $0,75 \%$ meningkatkan jumlah buah dan berat segar tanaman. Naikofi \& Rusae (2017) membuktikan bahwa aplikasi PGPR berpengaruh nyata terhadap berat kering akar tanaman selada.

Aplikasi PGPR yang tepat untuk kondisi lingkungan umumnya dan khususnya konsidi tanah di wilayah Kabupaten TTU belum diketahui sehingga perlu dilakukan penelitian tentang takaran dan frekuensi aplikasi PGPR pada tanaman selada. Tujuan penelitian ini adalah mengetahui dan membuktikan pengaruh takaran dan frekuensi aplikasi PGPR terhadap pertumbuhan dan hasil tanaman selada.

\section{Metode}

Penelitian dilaksanakan pada bulan September - Oktober 2017 di kebun penelitian Fakultas Pertanian Universitas Timor. Rancangan yang digunakan dalam penelitian ini adalah rancangan acak kelompok (RAK) faktorial dengan tiga kali ulangan. Faktor pertama adalah takaran PGPR (D) yang terdiri dari tiga aras yakni $25 \mathrm{~g}\left(\mathrm{~d}_{1}\right), 50 \mathrm{~g}\left(\mathrm{~d}_{2}\right)$ dan $75 \mathrm{~g}\left(\mathrm{~d}_{3}\right)$. Faktor yang kedua adalah frekuensi aplikasi (F) yang terdiri dari tiga aras yakni tanpa penyiraman/kontrol $\left(\mathrm{f}_{0}\right)$, satu kali penyiraman $\left(f_{1}\right)$, dan dua kali penyiraman $\left(f_{2}\right)$.

Benih yang digunakan adalah benih selada varietas Grand Rapids. Sebelum disemai benih selada terlebih dahulu direndam dalam air 51 yang diberikan PGPR selama 15 menit agar mikroba berkoloni dengan benih selada dapa tumbuh dengan baik dan terhindar dari hama dan penyakit. Persemaian berupa bale-bale dengan ukurannya tinggi $100 \mathrm{~cm}$, lebar $100 \mathrm{~cm}$, panjang $150 \mathrm{~cm}$. Media semai berupa campuran tanah ayakan dengan pupuk kandang sapi. Benih ditaburkan secara merata kemudian ditutup dengan tanah yang tipis dan disiram air dengan hati-hati. Pada umur 14 hari, benih dipindahkan langsung ke bedengan yang sudah disiapkan.

Tanah terlebih dahulu dibersihkan dari gulma serta vegetasi lainya selanjutnya dilakukan pengolahan. Pengolahan tanah dilakukan dengan menggunakan cangkul, kemudian tanah digemburkan. Lahan yang digunakan berukuran panjang $11,40 \mathrm{~m}$, lebar $4 \mathrm{~m}$ dengan luas lahan $45,6 \mathrm{~m}^{2}$. Lahan dibagi dalam tiga blok, di dalam setiap blok terdapat 9 petak percobaan dengan ukuran petak $1 \mathrm{~m}$ x $1 \mathrm{~m}$ sehingga secara keseluruhan terdapat 27 petak percobaan. Jarak antar petak $0,3 \mathrm{~m}$ dan jarak antar blok $0,5 \mathrm{~m}$. Pada setiap blok, petak, tanaman sampel dan tanaman korban diberikan label menggunakan tiang bambu dan seng. Penanaman dilakukan serempak pada semua petak pada sore hari dengan cara ditugal sedalam $3 \mathrm{~cm}$. Jumlah bibit per lubang adalah 1 bibit. Jarak tanam yang digunakan adalah $25 \times 25 \mathrm{~cm}$ sehingga dalam satu petak terdapat 16 tanaman selada.

PGPR dicampurkan dalam air 51 dengan takaran sesuai perlakuan yakni 25 g/5 1 air, $50 \mathrm{~g} / 51$ air dan $75 \mathrm{~g} / 51$ air. Larutan PGPR kemudian diberikan secara merata pada petak-petak percobaan sesuai dengan perlakuan. Pada sembilan petak percobaan diberikan satu kali pada saat penanaman dan pada sembilan petak percobaan diberikan dua kali yakni saat penanaman dan saat umur selada mencapai 14 HST. Penyiraman dilakukan dua kali sehari yaitu pagi dan sore hari kecuali pada hari dimana aplikasi PGPR dilakukan. Penyiraman dilakukan dengan menggunakan botol semprot agar volume air yang diberikan seragam pada setiap tanaman.

Parameter pengamatan berupa tinggi tanaman $(\mathrm{cm})$, jumlah daun (helai), luas daun $\left(\mathrm{cm}^{3}\right)$, berat segar trubus $(\mathrm{g})$, berat kering trubus $(\mathrm{g})$, berat segar akar $(\mathrm{g})$, berat kering akar $(\mathrm{g})$, berat segar tanaman $(\mathrm{g})$, berat kering tanaman $(\mathrm{g})$, bera segar tanaman per petak ( $t / h a)$, berat kering tanaman per petak ( $t / h a)$, dan indeks panen (\%). Semua data yang diperoleh ditabulasikan kemudian dianalisa dengan menggunakan sidik ragam (Anova) Rancangan Acak Kelompok (RAK), selanjutnya untuk mengetahui pengaruh perlakuan yang diberikan, rata-rata perlakuan diuji lanjut menggunakan Duncan Multiple Range Test (DMRT) pada a $5 \%$ sesuai petunjuk (Gomez \& Gomez, 1984). Analisis data menggunakan program SAS 9.1

\section{Hasil dan Pembahasan}

\subsection{Tinggi Tanaman}

Tanaman terus bertambah tinggi selama penelitian. Hasil sidik ragam (Anova) menunjukkan terjadi pengaruh interaksi antara takaran dan frekuensi PGPR pada setiap waktu pengamatan.

Walaupun demikian, perbedaan tinggi tanaman pada pengamatan 14 HST adalah perbedaan yang terjadi secara alami karena saat itu PGPR yang diaplikasikan untuk kedua kali baru diberikan, walaupun demikian secara visual terdapat perbedaan tinggi antara tanaman yang diberikan PGPR dan tanaman kontrol. 
Tabel 1. Tinggi Tanaman $(\mathrm{cm})$

\begin{tabular}{ccllll}
\hline Waktu & Frekuensi & \multicolumn{3}{c}{ Takaran PGPR } & \multirow{2}{*}{ Rerata } \\
\cline { 2 - 5 } Pengamatan & Aplikasi & $25 \mathrm{~g}$ & $50 \mathrm{~g}$ & $75 \mathrm{~g}$ & \\
\hline \multirow{3}{*}{$14 \mathrm{HST}$} & Kontrol & $5,56 \mathrm{bc}$ & $5,33 \mathrm{c}$ & $5,22 \mathrm{c}$ & 5,37 \\
& 1 Kali & $5,78 \mathrm{ab}$ & $5,67 \mathrm{bc}$ & $5,56 \mathrm{bc}$ & 5,67 \\
& $2 \mathrm{Kali}$ & $6,11 \mathrm{ab}$ & $5,67 \mathrm{bc}$ & $6,44 \mathrm{a}$ & 6.07 \\
\cline { 2 - 5 } & Rerata & 5,81 & 5,56 & 5,74 & $(+)$ \\
\hline \multirow{3}{*}{$21 \mathrm{HST}$} & Kontrol & $7,44 \mathrm{abc}$ & $7,11 \mathrm{c}$ & $7,22 \mathrm{bc}$ & 7,26 \\
& 1 Kali & $7,44 \mathrm{abc}$ & $7,56 \mathrm{abc}$ & $7,11 \mathrm{c}$ & 7,37 \\
& 2 Kali & $7,89 \mathrm{bc}$ & $7,67 \mathrm{abc}$ & $8,00 \mathrm{a}$ & 7,85 \\
\cline { 2 - 5 } $28 \mathrm{HST}$ & Rerata & 7,44 & 7,11 & 7,22 & $(+)$ \\
& Kontrol & $8,33 \mathrm{ab}$ & $8,33 \mathrm{ab}$ & $8,00 \mathrm{~b}$ & 8,22 \\
& 1 Kali & $8,56 \mathrm{ab}$ & $8,78 \mathrm{a}$ & $8,78 \mathrm{a}$ & 8,70 \\
& $2 \mathrm{Kali}$ & $8,33 \mathrm{ab}$ & $8,89 \mathrm{a}$ & $8,67 \mathrm{a}$ & 8,63 \\
\hline & Rerata & 8,41 & 8,67 & 8,48 & $(+)$ \\
\hline
\end{tabular}

Keterangan: Angka pada baris dan kolom diikuti huruf sama tidak berbeda pada taraf nyata $(\alpha) 5 \%$ menurut uji DMRT. (+): Terjadi interaksi antar faktor.

Saat pengamatan 21 HST, tanaman yang diberikan PGPR dua kali dengan takaran $75 \mathrm{~g}$ paling tinggi dan berbeda nyata dengan tinggi tanaman pada dua petak perlakuan kontrol dan juga berbeda nyata dengan tinggi tanaman yang diberikan PGPR satu kali dengan takaran yang sama, selain itu juga berbeda nyata dengan tinggi tanaman yang diberikan PGPR dua kali dengan takaran 25 g. Saat pengamatan 28 HST, tanaman yang diberikan PGPR dua kali dengan takaran $50 \mathrm{~g}$ paling tinggi dan berbeda nyata dengan tinggi tanaman pada salah satu petak perlakuan kontrol tetapi tidak berbeda nyata dengan tinggi tanaman dengan perlakuan lainnya.

\subsection{Jumlah Daun}

Daun tanaman terus bertambah banyak selama penelitian. Hasil sidik ragam (Anova) menunjukkan terjadi pengaruh interaksi antara takaran dan frekuensi PGPR pada setiap waktu pengamatan tetapi perbedaan jumlah daun tanaman pada pengamatan 14 HST adalah perbedaan yang terjadi secara alami karena saat itu PGPR yang diaplikasikan untuk kedua kali baru diberikan, walaupun demikian secara visual terdapat perbedaan jumlah daun tanaman yang diberikan PGPR dan tanaman kontrol.

Saat pengamatan $21 \mathrm{HST}$, tanaman yang diberikan PGPR satu kali dengan takaran $75 \mathrm{~g}$ paling banyak dan berbeda nyata dengan jumlah daun tanaman kontrol. Saat pengamatan 28 HST, daun tanaman yang diberikan PGPR dua kali dengan takaran $75 \mathrm{~g}$ paling banyak tetapi tidak berbeda nyata dengan jumlah daun tanaman yang diberikan PGPR satu kali dengan takaran yang sama dan jumlah daun tanaman yang diberikan PGPR dua kali dengan takaran $50 \mathrm{~g}$.

Tabel 2. Jumlah Daun (helai)

\begin{tabular}{|c|c|c|c|c|c|}
\hline \multirow{2}{*}{$\begin{array}{c}\text { Waktu } \\
\text { Pengamatan }\end{array}$} & \multirow{2}{*}{$\begin{array}{c}\text { Frekuensi } \\
\text { Aplikasi }\end{array}$} & \multicolumn{3}{|c|}{ Takaran PGPR } & \multirow[b]{2}{*}{ Rerata } \\
\hline & & $25 \mathrm{~g}$ & $50 \mathrm{~g}$ & $75 \mathrm{~g}$ & \\
\hline \multirow{4}{*}{$14 \mathrm{HST}$} & Kontrol & $3,33 \mathrm{f}$ & 3,67 ef & $3,22 \mathrm{f}$ & 3,41 \\
\hline & 1 Kali & $4,00 \mathrm{de}$ & $4,11 \mathrm{cde}$ & $4,22 \mathrm{~cd}$ & 4,11 \\
\hline & 2 Kali & $4,56 \mathrm{bc}$ & $4,78 \mathrm{ab}$ & $5,11 \mathrm{a}$ & 4,81 \\
\hline & Rerata & 3,96 & 4,19 & 4,19 & $(+)$ \\
\hline \multirow{4}{*}{$21 \mathrm{HST}$} & Kontrol & $4,89 \mathrm{c}$ & $5,00 \mathrm{bc}$ & $4,89 \mathrm{c}$ & 4,93 \\
\hline & 1 Kali & $5,44 \mathrm{ab}$ & $5,44 \mathrm{ab}$ & $5,56 \mathrm{a}$ & 5,48 \\
\hline & 2 Kali & $5,33 \mathrm{abc}$ & $5,22 \mathrm{abc}$ & $5,33 \mathrm{abc}$ & 5,30 \\
\hline & Rerata & 5,22 & 5,22 & 5,26 & $(+)$ \\
\hline \multirow{4}{*}{$28 \mathrm{HST}$} & Kontrol & $6,67 \mathrm{~d}$ & $6,78 \mathrm{~d}$ & $7,00 \mathrm{~cd}$ & 6,81 \\
\hline & 1 Kali & $7,11 \mathrm{~cd}$ & $7,33 \mathrm{bc}$ & $7,78 \mathrm{ab}$ & 7,41 \\
\hline & 2 Kali & $7,44 \mathrm{bc}$ & $8,00 \mathrm{a}$ & $8,11 \mathrm{a}$ & 7,85 \\
\hline & Rerata & 7,07 & 7,37 & 7,63 & $(+)$ \\
\hline
\end{tabular}

\subsection{Luas Daun}

Hasil sidik ragam (Anova) menunjukkan terjadi pengaruh interaksi antara takaran dan frekuensi PGPR terhadap luas daun. Tanaman yang diberikan PGPR dua kali dengan takaran $25 \mathrm{~g}$ memiliki permukaan daun yang paling luas dan berbeda nyata dengan luas daun tanaman control dan juga berbeda nyata dengan luas daun dari tanaman yang diberikan PGPR satu kali dengan takaran $75 \mathrm{~g}$.

Tabel 3. Luas Daun $\left(\mathrm{cm}^{2}\right)$

\begin{tabular}{|c|c|c|c|c|}
\hline \multirow{2}{*}{ Frekuensi Aplikasi } & \multicolumn{3}{|c|}{ Takaran PGPR } & \multirow{2}{*}{ Rerata } \\
\hline & $25 \mathrm{~g}$ & $50 \mathrm{~g}$ & $75 \mathrm{~g}$ & \\
\hline Kontrol & $702 \mathrm{~cd}$ & $624 \mathrm{~cd}$ & $546 \mathrm{~d}$ & 624 \\
\hline 1 Kali & $1092 \mathrm{ab}$ & $936 \mathrm{abc}$ & 858 bcd & 962 \\
\hline 2 Kali & $1326 \mathrm{a}$ & $1014 \mathrm{ab}$ & $1248 \mathrm{a}$ & 1196 \\
\hline Rerata & 1040 & 858 & 884 & $(+)$ \\
\hline
\end{tabular}

Keterangan: Angka pada baris dan kolom diikuti huruf sama tidak berbeda pada taraf nyata $(\alpha) 5 \%$ menurut uji DMRT. (+): Terjadi interaksi antar faktor.

\subsection{Berat Segar Trubus}

Hasil sidik ragam (Anova) menunjukkan terjadi pengaruh interaksi antara takaran dan frekuensi aplikasi PGPR terhadap berat segar trubus. Trubus segar tanaman selada yang diberikan PGPR dengan takaran $25 \mathrm{~g}$ sebanyak dua kali paling berat dan berbeda nyata dengan berat segar trubus selada yang tidak diberikan PGPR serta berat segar trubus selada yang diberikan PGPR dengan takaran yang sama tetapi diberikan hanya satu kali.

\begin{tabular}{|c|c|c|c|c|}
\hline \multirow{2}{*}{ Frekuensi Aplikasi } & \multicolumn{3}{|c|}{ Takaran PGPR } & \multirow{2}{*}{ Rerata } \\
\hline & $25 \mathrm{~g}$ & $50 \mathrm{~g}$ & $75 \mathrm{~g}$ & \\
\hline Kontrol & $64,75 \mathrm{~d}$ & $109,13 \mathrm{bcd}$ & $92,88 \mathrm{~cd}$ & 88,92 \\
\hline 1 Kali & $125,96 \mathrm{bc}$ & $161,68 \mathrm{ab}$ & $155,76 \mathrm{ab}$ & 147,80 \\
\hline 2 Kali & $192,04 \mathrm{a}$ & $151,04 \mathrm{ab}$ & $188,84 \mathrm{a}$ & 177,31 \\
\hline Rerata & 127,58 & 140,62 & 145,83 & $(+)$ \\
\hline
\end{tabular}

Hal ini menunjukkan bahwa aktivitas metabolic dari selada yang diberikan PGPR dengan takaran 25 g sebanyak dua kali berjalan lebih baik. Menurut Salisbury \& Ross (1995) berat segar trubus merupakan total berat tanaman yang menunjukan hasil aktivitas metabolic tanaman dan sudah terpisah dari akar tanaman.

\subsection{Berat Kering Trubus}

Hasil sidik ragam (Anova) menunjukkan terjadi pengaruh interaksi antara takaran dan frekuensi aplikasi PGPR terhadap berat kering trubus. Trubus kering tanaman selada yang diberikan PGPR dengan takaran 75 g sebanyak dua kali paling berat dan berbeda nyata dengan berat kering trubus selada yang tidak diberikan PGPR serta berat kering trubus selada yang diberikan PGPR dengan takaran yang sama tetapi diberikan hanya satu kali.

Tabel 5. Berat Kering Trubus (g)

\begin{tabular}{ccccc}
\hline \multirow{2}{*}{ Frekuensi Aplikasi } & \multicolumn{3}{c}{ Takaran PGPR } & \multirow{2}{*}{ Rerata } \\
\cline { 2 - 4 } & $25 \mathrm{~g}$ & $50 \mathrm{~g}$ & $75 \mathrm{~g}$ & \\
\hline Kontrol & $5,19 \mathrm{c}$ & $7,57 \mathrm{c}$ & $5,26 \mathrm{c}$ & 6,01 \\
1 Kali & $12,58 \mathrm{ab}$ & $11,63 \mathrm{ab}$ & $9,12 \mathrm{bc}$ & 11,11 \\
$2 \mathrm{Kali}$ & $15,44 \mathrm{a}$ & $11,76 \mathrm{ab}$ & $15,45 \mathrm{a}$ & 14,22 \\
\hline Rerata & 11.07 & 10.32 & 9.94 & $(+)$
\end{tabular}

Keterangan: Angka pada baris dan kolom diikuti huruf sama tidak berbeda pada taraf nyata $(\alpha) 5 \%$ Angka pada baris dan kolom diikuti huruf sama tidak
menurut uji DMRT. (+): Terjadi interaksi antar faktor.

Hal ini menunjukkan bahwa penimbunan hasil bersih asimilasi $\mathrm{CO}_{2}$ oleh selada yang diberikan PGPR dengan takaran $75 \mathrm{~g}$ sebanyak dua kali berjalan lebih baik. Hal ini sesuai dengan Larcher (2003) yang menyatakan bahwa berat kering trubus merupakan hasil dari penimbunan hasil bersih asimilasi $\mathrm{CO}_{2}$.

\subsection{Berat Segar Akar}

Hasil sidik ragam (Anova) menunjukkan terjadi pengaruh interaksi antara takaran dan frekuensi aplikasi PGPR terhadap berat segar akar. Akar tanaman selada yang diberikan PGPR dengan takaran $25 \mathrm{~g}$ sebanyak dua kali paling berat dan berbeda nyata dengan berat akar selada yang tidak diberikan PGPR serta berat akar selada yang diberikan PGPR dengan takaran yang sama tetapi diberikan hanya satu kali.

\section{Tabel 6. Berat Segar Akar (g)}

\begin{tabular}{ccccc}
\hline \multirow{2}{*}{ Frekuensi Aplikasi } & \multicolumn{3}{c}{ Takaran PGPR } & \multirow{2}{*}{ Rerata } \\
\cline { 2 - 4 } & $25 \mathrm{~g}$ & $50 \mathrm{~g}$ & $75 \mathrm{~g}$ & \\
\hline Kontrol & $4,74 \mathrm{c}$ & $8,38 \mathrm{ab}$ & $4,77 \mathrm{c}$ & 5.96 \\
1 Kali & $6,60 \mathrm{bc}$ & $9,16 \mathrm{a}$ & $9,53 \mathrm{a}$ & 8.43 \\
2 Kali & $10,77 \mathrm{a}$ & $8,99 \mathrm{a}$ & $10,18 \mathrm{a}$ & 9.98 \\
\hline Rerata & 7,37 & 8,84 & 8,16 & $(+)$ \\
\hline
\end{tabular}

Keterangan: Angka pada baris dan kolom diikuti huruf sama tidak berbeda pada taraf nyata $(\alpha) 5 \%$ menurut uji DMRT. (+): Terjadi interaksi antar faktor.

\subsection{Berat Kering Akar}

Hasil sidik ragam (Anova) menunjukkan terjadi pengaruh interaksi antara takaran dan frekuensi aplikasi PGPR terhadap berat kering akar.

Tabel 7. Berat Kering Akar (g)

\begin{tabular}{|c|c|c|c|c|}
\hline \multirow{2}{*}{ Frekuensi Aplikasi } & \multicolumn{3}{|c|}{ Takaran PGPR } & \multirow{2}{*}{ Rerata } \\
\hline & $25 \mathrm{~g}$ & $50 \mathrm{~g}$ & $75 \mathrm{~g}$ & \\
\hline Kontrol & $0,65 \mathrm{c}$ & $0,93 \mathrm{bc}$ & $0,68 \mathrm{c}$ & 0,75 \\
\hline 1 Kali & $1,21 \mathrm{ab}$ & $1,02 \mathrm{bc}$ & $1,39 \mathrm{a}$ & 1,21 \\
\hline 2 Kali & $1,40 \mathrm{a}$ & $1,24 \mathrm{ab}$ & $1,44 \mathrm{a}$ & 1,36 \\
\hline Rerata & 1,09 & 1,06 & 1,17 & $(+)$ \\
\hline
\end{tabular}

Akar tanaman selada yang diberikan PGPR dengan takaran $75 \mathrm{~g}$ sebanyak dua kali paling berat dan berbeda nyata dengan berat kering akar selada yang tidak diberikan PGPR serta berat kering akar selada yang diberikan PGPR dengan takaran $50 \mathrm{~g}$ yang diberikan satu kali.

\subsection{Berat Segar Tanaman}

Hasil sidik ragam (Anova) menunjukkan terjadi pengaruh interaksi antara takaran dan frekuensi aplikasi PGPR terhadap berat segar tanaman. Tanaman yang diberikan PGPR dengan takaran $25 \mathrm{~g}$ sebanyak dua kali paling berat dan berbeda nyata dengan berat segar tanaman yang tidak diberikan PGPR serta berat 
segar tanaman selada yang diberikan PGPR dengan takaran yang sama tetapi diberikan hanya satu kali.

Tabel 8. Berat Segar Tanaman (g)

\begin{tabular}{ccccc}
\hline \multirow{2}{*}{ Frekuensi Aplikasi } & \multicolumn{3}{c}{ Takaran PGPR } & \multirow{2}{*}{ Rerata } \\
\cline { 2 - 4 } & $25 \mathrm{~g}$ & $50 \mathrm{~g}$ & $75 \mathrm{~g}$ & \\
\hline Kontrol & $68,97 \mathrm{~d}$ & $118,49 \mathrm{~cd}$ & $76,03 \mathrm{~d}$ & 87,83 \\
$1 \mathrm{Kali}$ & $147,33 \mathrm{bc}$ & $169,94 \mathrm{ab}$ & $187,79 \mathrm{ab}$ & 168,35 \\
$2 \mathrm{Kali}$ & $220,35 \mathrm{a}$ & $171,07 \mathrm{ab}$ & $201,71 \mathrm{a}$ & 197,71 \\
\hline Rerata & 145,55 & 153,17 & 155,18 & $(+)$ \\
\hline Keterangan & Angka &
\end{tabular}

Keterangan: Angka pada baris dan kolom diikuti huruf sama tidak berbeda pada taraf nyata $(\alpha) 5$ menurut uji DMRT. (+): Terjadi interaksi antar faktor.

\subsection{Berat Kering Tanaman}

Hasil sidik ragam (Anova) menunjukkan terjadi pengaruh interaksi antara takaran dan frekuensi aplikasi PGPR terhadap berat kering tanaman. Bahan kering tanaman yang diberikan PGPR dengan takaran $25 \mathrm{~g}$ sebanyak dua kali paling berat dan berbeda nyata dengan berat kering tanaman yang tidak diberikan PGPR serta berat kering tanaman selada yang diberikan PGPR dengan takaran 75 g yang diberikan satu kali.

Tabel 9. Berat Kering Tanaman (g)

\begin{tabular}{|c|c|c|c|c|}
\hline \multirow{2}{*}{ Frekuensi Aplikasi } & \multicolumn{3}{|c|}{ Takaran PGPR } & \multirow[b]{2}{*}{ Rerata } \\
\hline & $25 \mathrm{~g}$ & $50 \mathrm{~g}$ & $75 \mathrm{~g}$ & \\
\hline Kontrol & $8,73 \mathrm{~cd}$ & $8,38 \mathrm{~cd}$ & $6,97 \mathrm{~d}$ & 8,03 \\
\hline 1 Kali & $14,21 \mathrm{ab}$ & $12,54 \mathrm{abc}$ & $11,37 \mathrm{bcd}$ & 12,71 \\
\hline 2 Kali & $17,01 \mathrm{a}$ & $13,74 \mathrm{ab}$ & $16,65 \mathrm{a}$ & 15,80 \\
\hline Rerata & 13,31 & 11,56 & 11,67 & $(+)$ \\
\hline
\end{tabular}

Keterangan: Angka pada baris dan kolom diikuti huruf sama tidak berbeda pada taraf nyata $(\alpha) 5 \%$ menurut uji DMRT. (+): Terjadi interaksi antar faktor.

\subsection{Berat Segar Tanaman Per Petak}

Hasil sidik ragam (Anova) menunjukkan terjadi pengaruh interaksi antara takaran dan frekuensi aplikasi PGPR terhadap berat segar tanaman per petak. Tanaman per petak yang diberikan PGPR dengan takaran $25 \mathrm{~g}$ sebanyak dua kali paling berat dan berbeda nyata dengan berat segar tanaman per petak yang tidak diberikan PGPR serta berat segar tanaman per petak yang diberikan PGPR dengan takaran yang sama tetapi diberikan hanya satu kali.

Tabel 10. Berat Segar Tanaman Per Petak (t/ha)

\begin{tabular}{|c|c|c|c|c|}
\hline \multirow{2}{*}{ Frekuensi Aplikasi } & \multicolumn{3}{|c|}{ Takaran PGPR } & \multirow{2}{*}{ Rerata } \\
\hline & $25 \mathrm{~g}$ & $50 \mathrm{~g}$ & $75 \mathrm{~g}$ & \\
\hline Kontrol & $0,34 \mathrm{~d}$ & $0,59 \mathrm{~cd}$ & $0,38 \mathrm{~d}$ & 0,44 \\
\hline 1 Kali & $0,74 \mathrm{bc}$ & $0,85 \mathrm{ab}$ & $0,94 \mathrm{ab}$ & 0,84 \\
\hline 2 Kali & $1,10 \mathrm{a}$ & $0,86 \mathrm{ab}$ & $1,01 \mathrm{a}$ & 0,99 \\
\hline Rerata & 0,73 & 0,77 & 0,78 & $(+)$ \\
\hline
\end{tabular}
menurut uji DMRT. (+): Terjadi interaksi antar faktor.

\subsection{Berat Kering Tanaman Per Petak}

Hasil sidik ragam (Anova) menunjukkan terjadi pengaruh interaksi antara takaran dan frekuensi aplikasi PGPR terhadap berat kering tanaman per petak. Bahan kering tanaman per petak yang diberikan PGPR dengan takaran $25 \mathrm{~g}$ sebanyak dua kali paling berat dan berbeda nyata dengan berat kering tanaman per petak yang tidak diberikan PGPR serta berat kering tanaman per petak yang diberikan PGPR dengan takaran $50 \mathrm{~g}$ yang diberikan satu kali.

Tabel 11. Berat Kering Tanaman Per Per Petak (t/ha)

\begin{tabular}{|c|c|c|c|c|}
\hline \multirow{2}{*}{ Frekuensi Aplikasi } & \multicolumn{3}{|c|}{ Takaran PGPR } & \multirow{2}{*}{ Rerata } \\
\hline & $25 \mathrm{~g}$ & $50 \mathrm{~g}$ & $75 \mathrm{~g}$ & \\
\hline Kontrol & $0,04 \mathrm{~cd}$ & $0,04 \mathrm{~cd}$ & $0,03 \mathrm{~d}$ & 0,04 \\
\hline 1 Kali & $0,07 \mathrm{ab}$ & $0,06 \mathrm{bcd}$ & $0,06 \mathrm{abc}$ & 0,06 \\
\hline 2 Kali & $0,09 \mathrm{a}$ & $0,07 \mathrm{ab}$ & $0,08 \mathrm{a}$ & 0,08 \\
\hline Rerata & 0,07 & 0,06 & 0,06 & $(+)$ \\
\hline
\end{tabular}
menurut uji DMRT. $(+)$ : Terjadi interaksi antar faktor.

\subsection{Indeks Panen}

Hasil sidik ragam (Anova) menunjukkan terjadi pengaruh interaksi antara takaran dan frekuensi aplikasi PGPR terhadap indeks panen.

Tabel 12. Indeks Panen (\%)

\begin{tabular}{|c|c|c|c|c|}
\hline \multirow{2}{*}{ Frekuensi Aplikasi } & \multicolumn{3}{|c|}{ Takaran PGPR } & \multirow{2}{*}{ Rerata } \\
\hline & $25 \mathrm{~g}$ & $50 \mathrm{~g}$ & $75 \mathrm{~g}$ & \\
\hline Kontrol & $88,93 \mathrm{~d}$ & 91,02 bc & $91,68 \mathrm{bc}$ & 91,21 \\
\hline $1 \mathrm{Kali}$ & $90,71 \mathrm{~cd}$ & $93,19 \mathrm{ab}$ & $93,95 \mathrm{a}$ & 92,62 \\
\hline 2 Kali & $92,98 \mathrm{ab}$ & $92,61 \mathrm{abc}$ & $92,17 \mathrm{~cd}$ & 92,59 \\
\hline Rerata & 90,87 & 92,94 & 92,60 & $(+)$ \\
\hline
\end{tabular}

Keterangan: Angka pada baris dan kolom diikuti huruf sama tidak berbeda pada taraf nyata $(\alpha) 5 \%$ menurut uji DMRT. (+): Terjadi interaksi antar faktor.

Indeks panen tanaman yang diberikan PGPR dengan takaran $75 \mathrm{~g}$ sebanyak satu kali paling berat dan berbeda nyata dengan indeks panen tanaman yang tidak diberikan PGPR serta indeks panen tanaman yang diberikan PGPR dengan takaran $25 \mathrm{~g}$ yang diberikan satu kali, juga berbeda nyata dengan indeks panen tanaman yang diberikan PGPR dengan takaran yang sama tetapi diberikan dua kali.

\subsection{Pembahasan}

Pemberian PGPR dengan takaran 25 g sebanyak dua kali pada tanaman memberikan hasil yang paling baik pada tanaman selada berupa berat segar maupun kering tanaman yang paling berat untuk setiap tanaman maupun setiap petaknya. Kondisi ini tercapai karena pemberian PGPR dengan takaran $25 \mathrm{~g}$ sebanyak dua kali pada tanaman memberikan pertumbuhan akar dan trubus yang lebih baik yang dibuktikan dengan berat segar akar maupun trubus yang paling berat. Tanaman yang dihasilkan memang tidak terlalu tinggi dengan jumlah daun yang tidak terlalu banyak tetapi memiliki permukaan daun yang paling luas.

PGPR yang merupakan kelompok bakteri yang dimanfaatkan sebagai pupuk hayati untuk membantu tanaman dalam suplai hara dan memperkuat tanaman terhadap serangan hama maupun penyakit tanaman (Soesanto, 2008), sehingga pemberian PGPR dengan dosis dan frekuensi yang tepat memberikan pertumbuhan dan hasil selada yang terbaik. Selain itu, menurut Egamberdieva $e$ al., (2015) Fungsi PGPR bagi tanaman yaitu mampu memacu pertumbuhan dan fisiologi akar serta mampu mengurangi penyakit atau kerusakan oleh serangga.

\section{Simpulan}

Interaksi antara takaran dan frekuensi aplikasi PGPR terjadi pada semua parameter pertumbuhan dan hasil selada yakni tinggi tanaman, jumlah daun, luas daun, berat trubus baik segar maupun kering, berat akar baik segar maupun kering, berat tanaman baik segar maupun kering, berat tanaman per petak baik segar maupun kering dan indeks panen. Aplikasi PGPR sebanyak dua kali dengan takaran $25 \mathrm{~g}$ memberikan pertumbuhan dan hasil tanaman selada yang terbaik.

\section{Pustaka}

AAK 1994. Bertanam Selada \& Andewi. Jakarta: Kanisius.

BPS Kab. TTU 2004. Timor Tengah Utara dalam Angka. Kefamenanu: Badan Pusat Statistik Kabupaten TTU.

Egamberdieva, D., Shrivastava, S. \& Varma, A. 2015. Plant-Growth-Promoting Rhizobacteria $(P G P R)$ and Medicinal Plants. Soil Biology. Berlin: Springer International Publishing.

Figuiredo, M.V.B., Seldin, L., Araujo, F.F. \& Mariano, R.L.L. 2010. Plant Growth Promoting Rhizobacteria: Fundamentals and Applications. Microbiology Monographs. Berlin: Springer.

Gomez, K.A. \& Gomez, A.A. 1984. Statistical Procedures for Agricultural Research. New York: John Wiley \& Sons.

Larcher, W. 2003. Physiological Plant Ecology: Ecophysiology and Stress Physiology of Functional Groups. Berlin: Springer Science \& Business Media.

Naikofi, Y.M. \& Rusae, A. 2017. Pengaruh Aplikasi PGPR dan Jenis Pestisida terhadap Pertumbuhan dan Hasil Tanaman Selada (Lactuca sativa, L.). Savana Cendana, 2(04): 71-73.

Onikawijaya, A. 2015. Pengaruh konsentrasi plant growth promoting rhizobacteria (PGPR) terhadap pertumbuhan tanaman selada (Lactuca sativa L.). [skripsi] UIN Sunan Kalijaga Yogyakarta. Tersedia di http://digilib.uin-suka.ac.id/19786/ [Diakses 25 November 2017].

Raka, I.G.N., Khalimi, K., Nyana, I.D.N. \& Siadi, I.K. 2012. Aplikasi Rizobakteri Pantoea agglomerans untuk Meningkatkan Pertumbuhan dan Hasil Tanaman Jagung (Zea mays, L.) Varietas Hibrida BISI-2. Agrotrop: Journal on Agriculture Science, 2(1): 1-9.

Rubatzky, V.E. \& Yamaguchi, M. 2012. World Vegetables: Principles, Production, and Nutritive Values. Berlin: Springer Science \& Business Media.

Salisbury \& Ross, C.W. 1995. Fisiologi Tumbuhan Jilid 2 : Biokimia Tumbuhan Bandung: ITB Press.

Samadi, B. 2014. Rahasia Budidaya Selada. Depok: Pustaka Mina.

Soesanto, L. 2008. Pengantar Pengendalian Hayati Penyakit Tanaman. 2 ed Jakarta: PT Raja Grafindo Persada.

Syamsiah, M. \& Rayani 2014. Respon Pertumbuhan dan Produksi Tanaman Cabai Merah (Capsicum Annum L.) terhadap Pemberian PGPR (Plant Growth Promoting Rhizobacteria) dari Akar Bambu dan Urine Kelinci. Agroscience, 4(2): 109-114.

Wicaksono 2008. Morfologi Tanaman Sayuran. Yogyakarta: Gajah Mada University Press. 